\title{
A New Strategy for Customer Engagement: How Do French Firms Use Social CRM?
}

\author{
Vincent Dutot $^{1}$ \\ ${ }^{1}$ ESG Management School, France \\ Correspondence: Vincent Dutot, ESG Management School, 25 rue St-ambroise, 75011 Paris, France. E-mail: \\ vdutot@esgms.fr
}

Received: September 17, 2012 Accepted: October 11, $2012 \quad$ Online Published: August 20, 2013

doi:10.5539/ibr.v6n9p54 URL: http://dx.doi.org/10.5539/ibr.v6n9p54

\begin{abstract}
A company is no longer only focused on winning market share or increasing demand, but also on customer relationships, engagement and retention. The idea of improving relationships with customers by using social media is called social customer relationship management (SCRM). The objective of this exploratory research is to define a grid of analysis of a SCRM strategy. To do so, a double analysis was conducted: a qualitative research on CAC 40 French firms and a quantitative survey on customer's perception of SCRM. Results show that most of the French top companies are not considering SCRM as much as customers (generation Y) want them to.
\end{abstract}

Keywords: social CRM, customer engagement, social media, measurement, perceived value

\section{Introduction}

Both the development of information technology and communication technologies and the emergence of e-business have changed existing business models. No longer focused solely on winning market share or increasing demand, companies are now expanding their focus to customer relationships and retention. Meanwhile, customer expectations are evolving toward greater interaction and personalization. Using Facebook, YouTube, Twitter, Wikipedia and blogs, customers are able to interact with nearly any company and express their opinions at their convenience. Moreover, social media appears to offer benefits to companies in all sectors. Although these benefits are difficult to translate into financial terms, they largely relate to increases in "customer insight and engagement" (Woodcock, Green, \& Starkey, 2011). This notion of improving relationships with customers using social media is known as social customer relationship management (SCRM). SCRM concerns people and relationships and requires an organization to adopt a customer-centric approach. Although this concept is rather new (Greenberg, 2009), recent studies have provided evidence of a link between SCRM and knowledge transfer within firms (Pavicic, Alfirevic, \& Znidar, 2011) as well as demonstrated the importance of incorporating social media into a firm's overall strategy to improve performance (Woodcock et al., 2011).

The objective of this exploratory research is to define a grid of analysis of an SCRM strategy. This grid is based on the concepts of customer relationship management and social media, and it aims to clarify the link among a CRM strategy, the use of social media and customer perceptions (Callarisa Fiol, Bigne Alcaniz, Moliner Tena, \& Shanchez Garcia, 2009; Chang, Wang, \& Yang, 2009). First, we seek to understand the relevance of SCRM in the French context (for both customers and top firms). Second, by exploring the CAC 40 French firms and their use of SCRM, we aim to draw a parallel between the tools implemented by these companies and customer perceptions of these tools, thus expressing the level of engagement in the customer relationship management (CRM) of the firms.

The following research question is considered: how do French firms use SCRM in their customer engagement strategies? In the first section, we present a review of the literature on CRM, social media, social CRM and the benefits of SCRM strategy as well as the research propositions. We then present the methodology and the results. Finally, we present the main contributions, limitations and future research suggestions.

\section{Literature Review}

This literature review defines the main concept of the study and presents both the principal theories and research proposition that are linked to the research question. The direction of this study is to present propositions (rather than hypotheses) for two main reasons: (1) the existing arguments in the literature are insufficient to determine the 
nature and strength of the relationship between variables, and (2) the innovative and exploratory character of the research does not efficiently lead to support for these links. Therefore, propositions (exploratory hypotheses) appear to be more suitable in this case (Evrard et al., 2009, p. 50).

\section{$2.1 C R M$}

Initially presented as a philosophy, CRM was once considered a customer-oriented strategy. It is now supported by technological tools and is useful in facilitating and improving customer relationships (Crosby, Johnson, \& Quinn, 2002; McKim, 2002; Dionne, 2001). Researchers define CRM as a means of developing a company's commitment to sustainable and profitable relationships with its most profitable customers (Torcy, 2002; Yorgey, 2002). Thus, CRM is as a key tool enabling a firm's differentiation from its competition (Almquist, Heaton, \& Hall, 2002).

CRM includes the management of technology, processes and informational and individual resources that are necessary to achieve objectives such as retention and attraction (Missi, Alshawi, \& Irani, 2002). Dionne (2001) explained CRM as a business strategy that is based on a methodology and supported by technology. The most comprehensive definition is that proposed by Grabner-Kraeuter and Moedritscher (2002), who considered CRM to be a customer-oriented business philosophy that includes the analysis, planning and control of customer relationships using information technology. Chen and Popovich (2003) have proposed that a CRM strategy or model should integrate the three dimensions of people, process and technology within the context of an enterprise-wide, customer-driven, technology-integrated and cross-functional organization (p. 675). Through this integration, a company can choose specific technologies to improve its performance and its knowledge of customers and to foster relationships with customers.

Thus, we can define CRM as the global process that enables a sustainable and profitable relationship between a company and its customers. CRM is primarily a marketing tool that is used to enhance customer value, and it comprises a set of concepts to be incorporated into a firm's overall business strategy.

Proposition 1: The CRM process should adjust the level of technology (and tools) to customer expectations to create value.

\subsection{Social Media}

Information technology (IT) has been recognized as a tool that enhances organizational performance (Davenport \& Short, 1990) and is an essential part of the CRM process within an organization (Chen \& Popovich, 2003). New technologies and innovation that rely on CRM are among the factors that enable one-to-one initiatives. As a result of Web 2.0 and social media, companies can develop their relationships to customize the shopping experience, to develop new products or to build beneficial long-term relationships.

The term "social media" has been used in several contexts related to different technologies and what they can they accomplish. Social media may be defined as the production, consumption and exchange of information across platforms for social interaction. Using a similar approach but without explicitly defining social media, Greenberg (2009) advocated that all customers are now "customer benefits" and that every interaction is an integral part of a new collaboration between the company and the customer, yielding CRM 2.0 (Andzulis, Panagopoulos, \& Rapp, 2012).

Social media may be understood as the set of Internet-based applications for the development of user-generated content (UGC) and provides a forum for interaction between users (O'Leary, 2011). In some cases, social media may be considered the technological support enabling the interaction and the development of virtual relationships. This technology is known as Web 2.0 (O'Reilly, 2005) or even enterprise 2.0 (McAfee, 2006).

More precisely, Proulx, Millette and Heaton (2012) defined social media as "media that allows users to maintain a presence, communicate and interact online." Social media has progressively allowed individuals to rely on the Internet to communicate, speak, read or comment (O'Leary, 2011). According to CREDOC (2009), 57\% of French Internet users consult the opinions of other users before purchasing various products and services. Specifically, these new media enable conversations between customers about such topics as products and company reputations. Before the development of social networks, companies retained control over the messages that they diffused and the time in which customers would have access to them. Companies now lose "control" once a message is broadcast as it is recovered by customers who will comment on, share or question it. The customer can "talk" directly with the brand and other customers (Mangold \& Faulds, 2009).

Today, companies are attempting to encourage customers (primarily Generation Y, those between 15 and 25 years old) to interact with them as they would with their friends and families on social networks. For their part, customers expect companies to be present on social networks (Nair, 2011). One of the most important aspects of 
social networks is that they allow a company to be active 24 hours per day, seven days per week, listening to remarks from their customers and adapting their business (Divol, Edelman, \& Sarrazin, 2012). Companies can thus create opportunities to "tell their story" (Ploof, 2009).

Proposition 2: The use of social media enables value co-creation based on collaboration between a company and its customers.

\subsection{Social CRM}

SCRM incorporates the principles of CRM using digital channels, such as social networks. Therefore, it does not replace traditional CRM but must rather be considered enrichment. This development follows the evolution of companies moving from a purely transactional logic to an interactional logic with its customers. SCRM is the answer provided by companies to the discussions created and generated by customers on social networks (Greenberg, 2009). For this reason, most large and medium-sized enterprises currently have a presence on social networks (e.g., Facebook pages, Twitter accounts).

SCRM is also termed "CRM 2.0" and relies on the empowerment of customers. This concept implies real transparency among companies, thus enabling trust from customers, who become more loyal and sometimes even advocates. The success and efficiency of this "customer engagement strategy" primarily result from the shift of companies' customer relationships into partner relationships. These changes affect the ways in which people interact with business, thus participating in companies' success. According to Mosadegh and Behboudi (2011), social CRM is defined as a specific strategy that aims to engage customers in a "collaborative interaction that provides mutually beneficial value in a trusted \& transparent business environment" (p. 66). In addition to enriching customer interactions, SCRM provides strategies for managing and measuring how social customers use social networking in engaging with a company.

In this orientation, SCRM is a philosophy as much as a business strategy. It is supported by a technological platform, business rules, processes and social characteristics and is designed to engage customers in a collaborative conversation to provide mutually beneficial value (Maoz, Jacobs, \& Davies, 2010). According to Chaffey (2011), social CRM is "the process of managing customer-to-customer conversations to engage existing customers, prospects or other stakeholders with a brand and so enhance CRM" (p. 483). He defines the "5 Ms of social CRM" as follows: (1) monitoring, (2) mapping, (3) management, (4) middleware and (5) measurement. This framework can be used to review or prioritize options of using social CRM within an enterprise.

Proposition 3: A successful CRM strategy for large companies should be based on social media to enhance the engagement of customers.

\subsection{Benefits, Internal Organization and Perceived Value of SCRM}

\subsubsection{Benefits and Internal Organization of SCRM}

Woodcock et al. (2011) noted that SCRM supports the entire customer management strategy and lifecycle and should thus lead to increased sales (through increased awareness and engagement) and decreased costs. According to the authors, SCRM can generate benefits for a company following a four-step process: engaging prospects and customers, conducting conversion (winning new customers), retaining customers and developing customer value. Therefore, SCRM supports the entire customer management strategy and lifecycle and should thus lead to increased sales (through increased awareness and engagement), decreased costs and customer value.

To organize its SCRM strategy, a company should integrate six strategic dimensions (cf. Table 1). These elements are primarily internal, whereas the tools that are used to maintain relationships with customers are external (e.g., blogs, social media, forums). By combining the two aspects (internal and external), companies can cover all aspects of a CRM strategy.

The elements presented in Table 1 allow us to identify specific criteria to be integrated into the grid (such as fans, content shares and delay) but, more importantly, may lead a company to improve its customer value. Indeed, by adding SM data to CRM data, companies can obtain a complete view of their customer relations and can thus plan specific strategies to interact with them. Such measures could also lead to an increase in the value given by customers to a specific company (termed "perceived value" in this study).

\subsubsection{Perceived Value of SCRM}

The role of perceived value is explained as follows: "offering superior value to the customer is essential for creating and maintaining long-term customer-supplier relationships" (Sharma, Krishnan, \& Grewal, 2001, p. 281; Eggert, Ulaga, \& Schultz, 2006). In this sense, perceived value is considered to be a co-creation process 
Table 1. Organizing SCRM (The customer framework, 2011)

\begin{tabular}{|c|c|}
\hline Dimension & Explanation \\
\hline Ensure leadership buy-in and support & $\begin{array}{l}\text { Culture, ways of working, measures and IT architecture must evolve; thus, } \\
\text { leadership is necessary. Leadership must be aware of the Social Media policy. }\end{array}$ \\
\hline Build and retain talent & $\begin{array}{l}\text { Finding appropriate resources to follow the SM strategy is essential. Finding } \\
\text { capable people and retaining them may be necessary. }\end{array}$ \\
\hline Evolve in terms of working culture & $\begin{array}{l}\text { The organization must determine whether it will exert global control or allow each } \\
\text { brand/market to become tribal in its development of SCRM. }\end{array}$ \\
\hline $\begin{array}{l}\text { Evolve in terms of the manner in which brand teams } \\
\text { plan, create, execute and review }\end{array}$ & $\begin{array}{l}\text { The organization must treat SCRM as a relevant and appropriate method for } \\
\text { developing customer engagement as part of the marketing mix. }\end{array}$ \\
\hline Change the nature of measurement and evaluation & $\begin{array}{l}\text { The organization must develop new measures, such as customer engagement, } \\
\text { number of fans, content shares, top conversations and response delay, to evaluate } \\
\text { its SCRM strategy. }\end{array}$ \\
\hline Develop the appropriate IT and data architecture & $\begin{array}{l}\text { SM data must be integrated with traditional CRM systems to paint a comprehensive } \\
\text { picture of customer behavior. }\end{array}$ \\
\hline
\end{tabular}

between firms and their customers (Callarisa Fiol et al., 2009; Prahalad \& Ramaswamy, 2004; Vargo \& Lush, 2004).

Perceived value is a concept that has been receiving an increasing amount of attention from industrial marketing researchers (Eggert et al., 2006; Ulaga \& Eggert, 2003) compared with other fields. Recently, an approach based on the conception of perceived value as a multidimensional construct has been gaining ground (Callarisa Fiol et al. 2009; Rust, Zeithaml, \& Lemmon, 2000). In recent papers, Eggert and Ulaga (2002) and Eggert et al. (2006) analyzed the sources of value creation in business marketing. These researchers examine beyond the traditional B2B view that is focused on the physical product and additionally consider relational dimensions. Nevertheless, as noted by Callariva Fiol et al. (2009), despite their multidimensional vision of perceived value, these papers do not consider the social component.

Chang et al. (2009) focused on the influence of a customer's perceived value on customer satisfaction and loyalty. As in previous works (Anderson \& Srinivasan, 2003; Chiu, Hsieh, \& Kao, 2005), the research of Chang et al. (2009) reinforces the link among these three concepts. For an organization, enhancing the perceived value of its customers can thus lead to greater loyalty.

Proposition 4: Companies should integrate both internal and external tools to improve the perceived value of SCRM.

Overall, the literature appears to have explored concepts such as CRM or social media separately. However, few studies have investigated social CRM and its effects on organizations. As suggested earlier, by developing strategies for improving customer relations, companies can generate benefits, enhance loyalty and improve their overall performance. Meanwhile, tools such as Facebook, Twitter or YouTube have become useful for customers seeking to create relationships with organizations. This research aims to fill the gap in the literature by relating the two main concepts within SCRM and by defining a grid of measurement of SCRM actions and testing it in the French context (by analyzing top companies and customers).

Following the literature review, the next section describes the methodology that is used to answer the research question: how do French firms use social CRM in their customer engagement strategy?

\section{Methodology}

To analyze firms in a phenomenological context, we have developed a normative grid that we tested (Table 2) and presented exploratory recommendations based on the results (Evrad, Bras, \& Roux, 2009). The grid was created following the literature and measures the degree of presence on Facebook and Twitter, the two most popular social networks in France. The grid comprises 10 criteria, with a score assigned to each criterion (between 0 and 100 points). The criteria were selected based on prior studies (primarily professional) on social media and marketing. The criteria and the grades were validated by 10 professionals specializing in social media and CRM. The final score in this research is the mean of the 10 evaluations by the professionals. By pre-testing and double-checking the grid, we followed the recommendations of Diamontopoulos and Winklhofer (2001), 
Table 2. Grid of measurement (CAC 40 firms)

\begin{tabular}{|c|c|c|c|}
\hline Criteria & Scale & Grade & Reference \\
\hline Industry & N/A & N/A & $\mathrm{N} / \mathrm{A}$ \\
\hline Fan/follower profile & $\begin{array}{l}\text { Fewer than } 15 ; 15-18 ; 19-25 \text {; } \\
26-35 ; 36-50 ; 51-60 ; \text { More than } \\
60\end{array}$ & N/A & N/A \\
\hline $\begin{array}{l}\text { Presence on social networks (we did } \\
\text { not consider professional social } \\
\text { networks, such as LinkedIn or } \\
\text { Viadeo) }\end{array}$ & $\begin{array}{l}\text { Facebook; Twitter; Pinterest; } \\
\text { YouTube; Google }+\end{array}$ & 10 points per social media & N/A \\
\hline \multirow{6}{*}{$\begin{array}{l}\text { Facebook: ("people talking about } \\
\text { this" + likes + comments)/number of } \\
\text { fans }\end{array}$} & $0-0.005 \%$ & 0 points & Payne (2011) \\
\hline & $0.005-0.05 \%$ & 10 points & Digibonus (2012) \\
\hline & $0.05-0.5 \%$ & 25 points & Broutin (2011) \\
\hline & $0.5-1 \%$ & 50 points & \\
\hline & $1-2 \%$ & 75 points & \\
\hline & $+2 \%$ & 100 points & \\
\hline \multirow[t]{5}{*}{ Facebook: frequency of publishing } & Less than once a week & 0 points & Payne (2011) \\
\hline & Once a week & 5 points & Deniaux (2012) \\
\hline & One to two times a week & 10 points & Arnold (2012) \\
\hline & Three to five times a week & 25 points & \\
\hline & More than five times a week & 50 points & \\
\hline \multirow{5}{*}{$\begin{array}{l}\text { Facebook: response time for a } \\
\text { question posted on the timeline }\end{array}$} & Less than two hours & 100 points & Vansnick (2011) \\
\hline & Between two and four hours & 75 points & Deniaux (2012) \\
\hline & Less than one day & 50 points & \\
\hline & Less than two days & 20 points & \\
\hline & More than two days & 0 points & \\
\hline \multirow[t]{7}{*}{ Facebook: tools on the page } & Quizzes and polls & 20 points & N/A \\
\hline & Commercial offers & 20 points & \\
\hline & F-shop & 20 points & \\
\hline & Event invitations & 20 points & \\
\hline & Forums & 50 points & \\
\hline & Social gaming & 50 points & \\
\hline & Chat & 100 points & \\
\hline \multirow[t]{6}{*}{ Twitter: following/followers } & $0-5 \%$ & 50 points & Deniaux (2012) \\
\hline & $5-10 \%$ & 30 points & \\
\hline & $10-25 \%$ & 20 points & \\
\hline & $25-50 \%$ & 10 points & \\
\hline & $50-75 \%$ & 5 points & \\
\hline & $+75 \%$ & 0 points & \\
\hline \multirow[t]{4}{*}{ Twitter: retweets/tweets } & & 0 points & Payne (2011) \\
\hline & & 5 points & Deniaux (2012) \\
\hline & & 10 points & \\
\hline & & 25 points & \\
\hline
\end{tabular}




\begin{tabular}{|c|c|c|c|}
\hline Criteria & Scale & Grade & Reference \\
\hline & & 50 points & \\
\hline \multirow[t]{5}{*}{ Twitter: frequency of publishing } & Less than once a week & 0 points & Payne (2011) \\
\hline & Once a week & 5 points & Deniaux (2012) \\
\hline & One to two times a week & 10 points & \\
\hline & One to two times a day & 25 points & \\
\hline & More than two times a day & 50 points & \\
\hline \multirow[t]{4}{*}{ Twitter: time to respond to a question } & No answer & 0 points & Vansnick (2011) \\
\hline & $\begin{array}{l}\text { Respond to the question } \\
\text { (regardless of delay) }\end{array}$ & 50 points & Payne (2011) \\
\hline & Respond within a day & 100 points & \\
\hline & Specific SAV account on Twitter & Bonus 100 points & \\
\hline
\end{tabular}

In this exploratory research, we conducted a double analysis. In the first analysis, we tested the grid on CAC 40 French firms, seeking to understand and define their SCRM strategy. This analysis used the Internet as the primary source of information (Bernard, 2004; Kozinets, 2002; Bertrandias \& Carricano, 2006). From the 40 firms, we extracted only the B2C firms (29 were ultimately selected and analyzed). For each firm, we investigated its presence on social networks and assigned a score based on the criteria outlined.

The second analysis is customer-based and focuses on the interpretation and perception of social CRM strategies developed by enterprises. We launched an online survey and targeted actual users of social networks from Generation Y (15-25 years old). The survey was produced using Sphinx and was relayed on major social networks (such as Facebook and Twitter) during a one-month period, and 152 usable answers were collected. The survey is structured in three parts and is composed of 21 questions. The first part concerns general questions regarding the respondents and their use of social networks. The second part provides information on the relations between customers, brands and companies on social networks. Finally, the third part concerns the evolution of customer relationships through social networking platforms. The majority of the survey respondents were female $(56 \%)$, were 18 to 25 years old $(67 \%)$ and were students $(57 \%)$; $93 \%$ of them were active on Facebook (48\% on Twitter and $32 \%$ on Google + ) and reported connecting to social media several times per day (79\%). A large majority believed that companies should be present on social networks $(3.24 / 5 ; 65 \%$ agreement); for this sample, there is a clear link between presence on social networks and proximity with customers $(3.23 / 5 ; 64 \%$ agreement $)$. A total of $73 \%(\mathrm{n}=111)$ believe that the initial interaction between any organization and its customers should occur on social networks. However, it is important to note that only $36 \%(n=55)$ of customers reported using social networks to obtain information about firms for the first time (cf. Table 3). Search engines appear to be more popular and useful than social networks.

Table 3. Descriptive statistics $(\mathrm{n}=152)$

\begin{tabular}{lcccc}
\hline Criteria & Mean & Min & Max & Standard deviation \\
\hline Companies must be present on social networks & 3.24 & 1 & 5 & 0.53 \\
There is a link between having a social network presence & 3.23 & 1 & 5 & 0.57 \\
and proximity with customers & & & & 0.24 \\
Use of social network for initial interactions with company & 1.8 & 1 & 3 & 0.65 \\
Relationship between customers and organizations & 3.2 & 1 & 5 & \\
\hline
\end{tabular}

\section{Results and Discussion}

\subsection{Test of the Grid: Focus on CAC 40 Firms}

These results show that in France, CAC 40 firms have not defined SCRM as one of their main strategies. Moreover, we can observe a difference between industries. Telecommunication and automobile companies 
appear to be more active on social networks, whereas the luxury goods industry is relatively late in its introduction and use of SCRM components in their customer strategy (Table 4).

Table 4. Classification of enterprises

\begin{tabular}{|c|c|c|}
\hline Enterprise & Industry & Total score \\
\hline Bouygues Télécom & Telecommunication & 535 \\
\hline SFR & Telecommunication & 455 \\
\hline Carrefour & Retail & 425 \\
\hline France Télécom (Orange) & Telecommunication & 425 \\
\hline Peugeot & Automobile & 385 \\
\hline Citroën & Automobile & 385 \\
\hline Renault & Automobile & 375 \\
\hline AXA & Insurance & 375 \\
\hline Accor & Hotel & 360 \\
\hline BNP Paribas & Bank & 345 \\
\hline Fnac (PPR) & Distribution & 335 \\
\hline GDF Suez & Service/Energy & 335 \\
\hline Canal+ & Television & 325 \\
\hline Crédit Agricole & Bank & 310 \\
\hline Électricité de France & Service/Energy & 305 \\
\hline L'Oréal & Beauty/Cosmetics & 300 \\
\hline Essilor International & Service/Health & 265 \\
\hline Louis Vuitton & Luxury & 250 \\
\hline Alcatel-Lucent & Telecommunication & 250 \\
\hline Cap Gemini & Internet & 230 \\
\hline Total & Energy & 210 \\
\hline Dior & Luxury & 210 \\
\hline Legrand & Construction & 185 \\
\hline Société Générale & Bank & 180 \\
\hline Danone & Alimentation & 175 \\
\hline Martell (Pernod Ricard) & Wine & 165 \\
\hline Yves St Laurent (PPR) & Luxury & 160 \\
\hline Ricard (Pernod Ricard) & Alcohol & 160 \\
\hline Michelin & Tires & 155 \\
\hline
\end{tabular}

Based on these results, we were able to define the mean profile of French firms developing SCRM strategies (Table 5).

Overall, the results emphasize that companies are not considering social media as a means of supporting customer relationships. The following sub-sections highlight some of the criteria. 
Table 5. Mean profile of French firms

\begin{tabular}{ll}
\hline Criteria & Mean (n=29) \\
\hline Fan profile & $18-34$ years old \\
Social media attendance & $32 / 40$ \\
Facebook: "people talking about this"/fans x 100 & $70 / 100$ \\
Facebook: frequency of publication & $24 / 50$ \\
Facebook: response time & $28 / 100$ \\
Facebook: CRM tools & $51 / 280$ \\
Twitter: following/followers & $27 / 50$ \\
Twitter: frequency of publication & $17 / 50$ \\
Twitter: response time & $48 / 200$ \\
Total & $295 / 870$ \\
\hline
\end{tabular}

\subsubsection{Focus on Facebook}

The first criterion of interest is the response time on Facebook. The objective of this test was to measure the involvement and responsiveness of firms. The average score of 28 points indicates that French companies generally respond within two days. This result is disappointing because the primary benefits of social networks

are speed, interactivity and engagement (as highlighted by Woodcock et al., 2011). According to many professionals, the ideal response time on social networks is within two hours (Vansnick, 2011). Note that 10 of the companies analyzed exceeded two days for response time, and only two of the top 40 firms have an average response time within two hours.

Representing the second criterion are CRM tools on Facebook. To improve their customer relationships on social networks, companies can implement 2.0 customer relationship tools to promote interaction on their pages, such as commercial offers and games. The average rating is 51 points (cf. Table 4), which is much less than the mean for this criterion (140). Among the 29 companies studied, seven had a score of 0 points, indicating they do not employ any of the tools (quizzes or games) on social networks. We can separate the results into two groups. The first group comprises 13 companies with scores that are equal or greater than 70 points. The companies in this group have implemented tools such as social games, FAQs or Facebook Chat as well as quizzes, contests or invitations to events. Some companies even score over 100 points (SFR, BNP Paribas, GDF Suez and PSA), which clearly indicates that the development of customer relationship 2.0 tools is part of their SCRM strategy. The second group is composed of the bottom 16 companies (with scores of fewer than 70 points). This group contains the companies that have only recently begun integrating SCRM into their overall strategy (Renault, Louis Vuitton) and those that have not yet considered such tools in relation to their strategies (Ricard, Michelin or Yves Saint Laurent).

\subsubsection{Focus on Twitter}

The last two criteria concern Twitter. The first criterion is the frequency of publication on Twitter. When a company publishes content, it promotes interaction with customers and thus promotes activity on its page. The average score for this test is 17 points, which indicates that the average company "tweets" less than once per day. This result appears to be below the expected rating (50 points), which corresponds to more than two times per day.

Observing response times on Twitter, we have noted that half of the companies surveyed do not respond to their customers. Companies that adopt strategies to meet the needs of their customers invest in staff members that are trained to respond quickly and to develop a specific portal called "service" which is the digital representation of traditional service.

These initial results allow us to reinforce two of our research propositions. It appears that for some sectors and specific firms (telecommunication and automobile), a CRM strategy must include a social media presence (proposition 3). Companies such as Bouygues Telecom have even communicated their social media strategy and consider it a key advantage. We can also highlight the finding that companies are developing and using a wide range of tools on these social networks. The top five companies in our grid use nearly all of the tools available 
on Facebook or Twitter to be interactive and to facilitate collaboration with customers. Moreover, they hire individuals to specifically serve as resources (such as a community manager) who answer most of the queries made on their online platforms within two hours (proposition 4). It could be interesting to study the industries separately and to seek to understand why sectors such as luxury goods (in which customer loyalty is predominant) or banks are not yet investing in social media while the telecommunication or automobile industries are already using social media as part of their CRM strategy.

Following the presentation of how companies are considering social media in their CRM strategies and understanding their tools to enhance interaction and engagement, the next section focuses on customer perceptions of SCRM strategies.

\subsection{Customer Perceptions of SCRM}

The first part of the discussion reveals the reasons that customers use social media (Figure 1). The results show that social networks are used not only to communicate or share ideas with other customers or to find friends but also to obtain information regarding enterprises or brands and to provide recommendations (positive and negative).

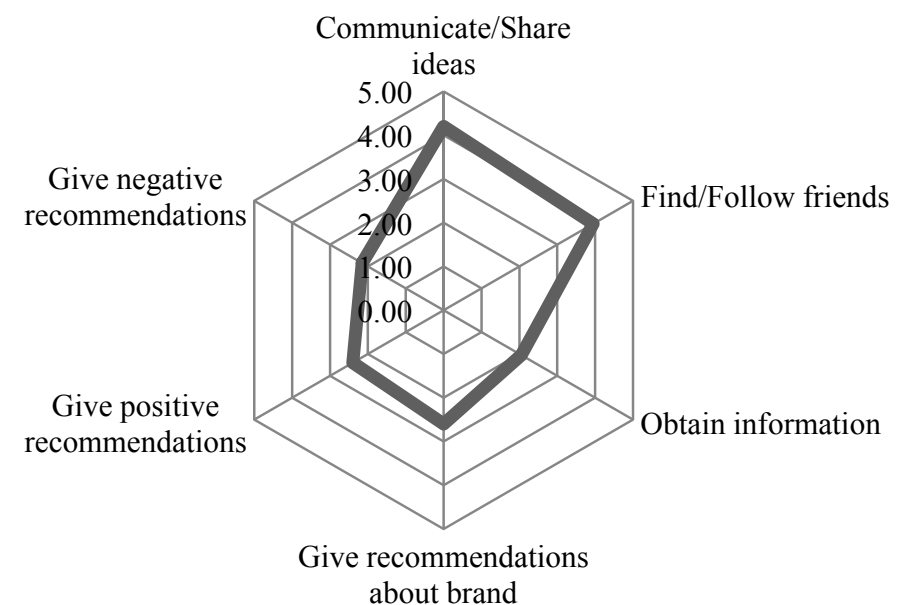

Figure 1. Customers' reasons for using social networks $(\mathrm{n}=152)$

Figure 2 highlights which company-related actions social networks should enable customers to take. In other words, this figure seeks to illustrate customer expectations of social networks. We observe two main expectations: (1) contacting the company through social networks and (2) following the company (e.g., trends, new products). Opportunities to discover exclusive content or special offers lag far behind.

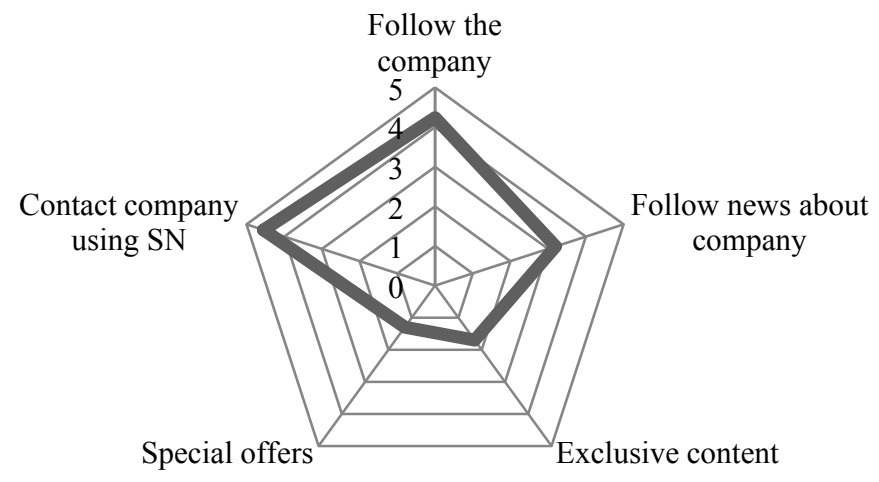

Figure 2. Customer expectations of social networks $(n=152)$ 
The analyses highlight two specific topics. The first topic concerns customer expectations regarding SCRM and the manner in which French firms respond to them (or not). The second concerns the tools that are necessary for a successful SCRM strategy.

\subsubsection{Customer Expectations of CRM}

Our analysis emphasizes that customers follow brands to remain aware of their activity but not necessarily to communicate with them; this finding casts doubt on ideas regarding social network interactions (cf. Table 6). In this case, publishing on a regular basis should be an important factor in the SCRM strategy of firms. However, our study suggests that most companies do not publish frequently on Facebook and Twitter (only six offer contributions on a daily basis on Facebook, and half of them publish less than once per day on Twitter). Firms should improve their frequency of publications to meet customer expectations regarding the two most popular social networks (Vansnick, 2011; Payne, 2011).

Table 6. Expectations of customers regarding SCRM

\begin{tabular}{lcccc}
\hline Expectations & Mean $(\mathrm{n}=152)$ & Min & Max & Standard deviation \\
\hline Following news about the company & 3.4 & 1 & 5 & 0.34 \\
Special offers & 2.5 & 1 & 4 & 0.14 \\
Exclusive invitations & 2 & 1 & 4 & 0.78 \\
\hline
\end{tabular}

The second criterion on which firms must improve is the response time for customer questions or queries. In our customer analysis, we noted that among customer expectations, opportunities for direct (e.g., chat) or semi-direct (e.g., FAQs or forums) dialogue are increasing. However, only one-third of the French firms studied appear to be present on Facebook, and only half of firms are engaging their customers on Twitter. There is a significant difference between customer expectations and the actual actions of top firms (proposition 1).

These initial results appear to suggest a significant difference between what customers want with regard to company presence on social media and where these companies are active. Expectations are high, but allowing customers to comment, to share ideas, and even to recommend the brand to other customers, are now aspects of CRM strategy. Therefore, companies should therefore adjust their social media activity to meet customer expectations (proposition 1). Generation $\mathrm{Y}$ is far more connected to social networks than any other range of population (91\% vs. less than $50 \%$ for other age groups), and any company seeking loyalty and potential customers should incorporate these customers into their CRM strategy.

\subsubsection{Tools to Transform Customer Relations on Social Networks}

Some of the results suggest changes in customer relationships resulting from social networks (from the customer or firm perspective). First, $90 \%$ of the respondents believe that there must be a relationship between customers and firms on social networks. This belief could drive companies to use social media as a new means of fostering relationships with their customers. Thus, although e-mail has been one of the most frequently used ways to establish contact with a company, we note that Facebook now appears to be the first choice for initiating an online relationship (Figure 3).

The use of 2.0 tools is gradually becoming the standard. Indeed, an increasing number of customers are willing to communicate or interact with companies using specific tools (e.g., quizzes, F-shops, special online offers, forums, chat). However, there remains much work for firms, as customers now expect significantly more engagement in the form of commercial offers, invitations to events and interactions. Indeed, our study shows that CAC 40 French firms involve more than 1\% of their Facebook communities (engagement), which is a good sign because it demonstrates their involvement with their communities. The average ratio of engagement (for an e-commerce firm) is $0.116 \%$ (socialbakers, 2012). Therefore, the top French companies appear to have understood that an engagement strategy is essential in the CRM process (proposition 3).

This research highlights a transformation in CRM through the development of social networks. By using new tools (e.g., chat, SAV on Twitter), customers can enhance their ability to communicate, share and become more than simply passive targets for companies, and by developing these technologies, companies will be able to enhance their performance (Trainor, 2012). To follow this shift, firms have developed new strategies (e.g., commercial offers, events, interaction tools) and have defined new positions within the organizations (e.g., community manager, specific customer service team on social networks). These strategies are not linked to 
traditional CRM strategies but are developed specifically for the SCRM approach (proposition 4, consistent with the findings of Ang, 2011).

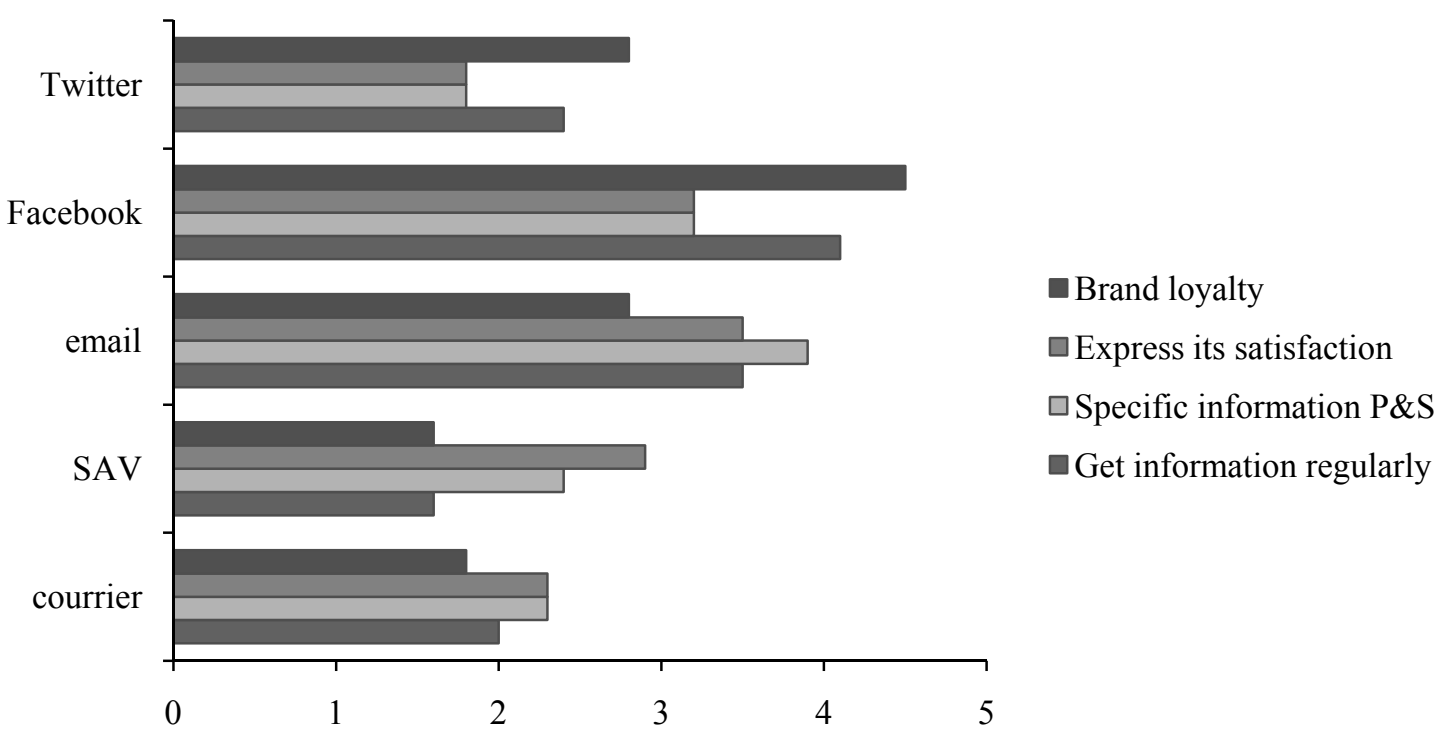

Figure 3. Tools used for customer relations $(\mathrm{n}=152)$

However, despite the expectations of customers and good will from companies, this study shows that only a few CAC 40 firms have a clear and distinguished SCRM strategy. For example, throughout our study of 29 companies, we observed only two Twitter portal services developed (SFR and Orange) and a single "Facebook Chat," which was implemented by Dolce Vita (GDF Suez).

\subsubsection{Relationship between SCRM and Perceived Value}

The results show a link between SCRM and customers' perceived value (propositions 2 and 4). As presented previously, customers believe that a social link should be established between them and companies and that this link should be the primary method of contact. This social relationship may be compared to that studied by Callarisa Fiol et al. (2009) and may thus be related to enhanced performance. Moreover, this strategy of using SCRM can lead to greater satisfaction and proximity to customers (through collaboration, the sharing of ideas or the co-creation of a product) and may promote a long-term perspective of loyalty. As highlighted by the results, the customer perspective shows a clear link between a social presence and greater proximity in their relationship with companies (which supplements the results of Chang et al. 2009).

\section{Conclusion}

The objectives of this research on social CRM strategies were to (1) define a grid of analysis of SCRM and (2) obtain a better understanding of SCRM in France by analyzing customer expectations and the presence of large French firms on social networks. The results show that most of the top French companies are not considering SCRM to the degree desired by customers. Customers expect organizations to be present on social networks, to interact with them and to propose different ways to initiate and maintain relations (propositions 1 and 4). By doing so, firms can enhance the process of collaboration, co-creation and engagement with their customers as well as brand perception (propositions 2 and 3, Maoz et al., 2010; Mosadegh \& Behboudi, 2011) and thus improve satisfaction and loyalty from a long-term perspective (Callarisa Fiol et al., 2009; Pavicic et al., 2011).

This study offers important scientific and managerial contributions. First, we sought to add to the current literature on CRM by focusing on the social dimension. By highlighting that customers expect firms to be present on social networks, we have expanded the traditional view of CRM. We also added to the contributions of social media in the literature. Indeed, many studies have investigated the influence of social network on performance, but few have succeeded in obtaining verifiable results. Further examination of engagement and customer relationships may facilitate the measurement of the influence of social media. 
In this study, managers may find some of the key success factors related to SCRM strategies and thereby identify the most critical tools for enhancing customer engagement. Managers may also gain insight into the expectations of Generation Y customers with respect to the customer relationship, collaboration and loyalty. Moreover, this study highlights the finding that in certain industries, companies are increasingly willing to develop SCRM tools and strategies to enhance customer engagement and perceived value.

Our study has inherent limitations. Indeed, we limited the research to France and its top B2C firms. It may be difficult to generalize the results from this study to other countries or other firms. In addition, the majority of our respondents were Generation Y customers (those aged 18-25). Although these customers are the most represented category on the Web and use social media in their daily lives, it would have been interesting to consider more respondents from other age categories. With regard to firms, we must consider the temporality factor: we analyzed what we observed on the business pages at the time of the study. Therefore, some companies may have implemented some tools since the study occurred, and such activity would likely change the final scores that such companies received in this research.

Several avenues may be proposed for future research. As we noted in our introduction, this research is exploratory and will lead to a larger study of the effects of SCRM on satisfaction and loyalty resulting from customers' perceived value. Thus, we would like to study the influence of various factors on engagement (causal links) by conducting a quantitative study and by highlighting the reasons that companies are not making greater use of SCRM based on consumer preferences. Other studies could also be conducted in other countries. Furthermore, future research could study a specific industry to improve our knowledge of specific trends (telecommunications) or could attempt to conduct a deeper comparison among industries. Finally, it would be beneficial to add other components to our grid to ensure a good representation of SCRM (such as the use of other social networks and social media use by Generation X).

\section{References}

Almquist, E., Heaton, C., \& Hall, N. (2002). Making CRM Make Money. Marketing Management, 11(3), 16-21.

Anderson, R. E., \& Srinivasan, S. S. (2003). E-satisfaction and e-loyalty: A contingency framework. Psychology \& Marketing, 20(2), 123-138. http://dx.doi.org/10.1002/mar.10063

Andzulis, J. M., Panagopoulos, N. G., \& Rapp, A. (2012). A Review of Social Media and Implications for the Sales Process. Journal of PersonalSelling\& Sales Management, 32(2), 305-316. http://dx.doi.org/10.2753/PSS0885-3134320302

Ang, L. (2011). Is SCRM really a good social media strategy? Database Marketing \& Customer Strategy Management, 18(3), 149-153. http://dx.doi.org/10.1057/dbm.2011.22

Arnold, M. J. (2012). Optimizing Facebook engagement: the timing of posts. Retrieved from $\mathrm{http} / / /$ socialmediatoday.com/morgan-j-arnold/597966/optimizing-facebook-engagement-timing-posts

Bemard, Y. (2004). La netnographie; une nouvelle méthode d'enquête qualitative basée sur les communautés virtuelles de consommation. Décisions Marketing, 36, 49-62.

Bertrandias, L., \& Carricano, M. (2006). Le prix derrière l'écran: étude netnographique d'une communauté virtuelle de professionnels de la fixation des prix. Décisions Marketing, 41, 53-66.

Broutin, A. (2011). Comment calculer le taux d'engagement d'une page Facebook? Retrieved from http://www.amelie-broutin.com/2011/12/06/comment-calculer-le-taux-d-engagement-d-une-page-facebook/

Callarisa, F. L. J., Bigne, A. E., Moliner, T. M. A., \& Shanchez, G. J. (2009). Customer loyalty in clusters: perceived value and satisfaction as antecedents. Journal of business to business marketing, 16, 276-316. http://dx.doi.org/10.1080/10517120802496878

Chaffey, D. (2011). E-business \& E-commerce management, strategy, implementation and practice (5th ed.). Prentice Hall.

Chang, H. H., Wang, Y. H., \& Yang, W. Y. (2009). The impact of e-service quality, customer satisfaction and loyalty on e-marketing: Moderating effect of perceived value. Total Quality Management, 20(4), 423-443. http://dx.doi.org/10.1080/14783360902781923

Chen, I. J., \& Popovich, K. (2003). Understanding customer relationship management (CRM): People, process and technology. Business Process Management, 9(5), 672-688. http://dx.doi.org/10.1108/14637150310496758

Chiu, H. C., Hsieh, Y. C., \& Kao, C. Y. (2005). Website quality and customer's behavioural intention: An 
exploratory study of the role of information asymmetry. Total Quality Management \& Business Excellence, 16(2), 185-198. http://dx.doi.org/10.1080/14783360500054277

CREDOC (2009). La diffusion des technologies de l'information et de la communication dans la société française. Retrieved from http://www.arcep.fr/uploads/tx_gspublication/etude-credoc-2009-111209.pdf

Crosby, L. A., Johnson, S. L., \& Quinn, R. T. (2002). Is Survey Research Dead? Marketing Management, 11(3), 24-29.

Davenport, T. H., \& Short, J. E. (1990). The New Industrial Engineering-Information Technology and Business Process Redesign. Sloan Management Review, 31(4), 11-27.

Deniaud, C. (2012). Medias Sociaux. Retrieved from http://www.mediassociaux.fr/author/cdeniaud/

Diamantopoulos, A., \& Winklhofer, H. M. (2001). Index Construction with formative indicators: an alternative to scale development. Journal of Marketing Research, 38(2), 269-277. http://dx.doi.org/10.1509/jmkr.38.2.269.18845

Dionne, M. (2001). Pour comprendre le CRM: La logique des poupées russes. Retrieved from www.crmodyssey.com

Divol, R., Edelman, D., \& Sarrazin, H. (2012). Demystifying Social Media (2nd ed.). McKinsey Quarterly.

Eggert, A., \& Ulaga, W. (2002). Customer perceived value: A substitute for satisfaction in business markets? Journal of Business and Industrial Marketing, 17(2/3), 107-118. http://dx.doi.org/10.1108/08858620210419754

Eggert, A., Ulaga, W., \& Schultz, F. (2006). Value creation in the relationship life cycle: A quasi longitudinal analysis. Industrial Marketing Management, 35, 20-27. http://dx.doi.org/10.1016/j.indmarman.2005.07.003

Evrard, Y., Pras, B., \& Roux, E. (2009). Market: Etudes et Recherches en Marketing. Paris: Dunod.

Grabner, K. S., \& Moedritscher, G. (2002). Alternative Approaches toward Measuring CRM.

Kozinets, R. (2002). The field behind the screen: using netnography for marketing research in online communities. Journal of Marketing Research, 39, 61-72. http://dx.doi.org/10.1509/jmkr.39.1.61.18935

Mangold, W. G., \& Faulds, D. J. (2009). Social media: The new hybrid element of the promotion mix. Business Horizons, 52(4), 357-365. http://dx.doi.org/10.1016/j.bushor.2009.03.002

Maoz, M., Jacobs, J., \& Davies, J. (2009). Predict 2010: customer service meets Social CRM. Gartner RAS core Research, Note G00172347.

McAfee, A. P. (2006). Enterprise 2.0: The dawn of emergent collaboration. MIT Sloan Management Review, 47(3), 21-28.

McKim, B. (2002). CRM: Beyond the Hoopla. Target Marketing, 25(7), 38-39.

Missi, F., Alshawi, S., \& Irani, Z. (2002). Customer Relationship Management in the EBusiness: Data Integration Issues. 7th conference of Association Information Management, 1-9.

Mosadegh, M. J., \& Behboudi, M. (2011). Using social network paradigm for developing a conceptual framework in CRM. Australian Journal of Business and Management Research, 1(4), 63-71.

Nair, M. (2011). Understanding and measuring the value of social media. The Journal of Corporate Accounting \& Finance, 22(3), 45-51. http://dx.doi.org/10.1002/jcaf.20674

O'Reilly (2005). What is Web 2.0. Retrieved from http://oreilly.com/web2/archive/what-is-web-20.html

O'Leary, D. E. (2011). The use of social media in the supply chain: survey and extensions. Intelligent Systems in Accounting, Finance \& Management, 18(2/3), 121-144. http://dx.doi.org/10.1002/isaf.327

Pavicic, J., Alfirevic, N., \& Znidar, K. (2011). Customer Knowledge Management: Toward Social CRM. International Journal of Management Cases, 13(3), 203-209.

Payne, K. D. (2011). Measure what matters: Online tools for understanding customers, social media, engagement, and key relationships (1st ed.).

Performance. 6th Research Conference on Relationship Marketing and Customer Relationship Management. Atlanta. June 9-12, 1-16.

Prahalad, C. K., \& Ramaswamy, V. (2004). Co-creation experiences: The next practice in value creation. Journal of Interactive Marketing, 18(3), 5-15. http://dx.doi.org/10.1002/dir.20015 
Proulx, S., Millette, M., \& Heaton, L. (2012). Media sociaux enjeux pour la communication, édition Presses de l'université du Québec.

Rust, R., Zeithaml, V., \& Lemmon, K. (2000). Driving customer equity. New York: The Free Press.

Sharma, A., Krishnan, R., \& Grewal, D. (2001). Value creation in markets: A critical area of focus for business-to-business markets. Industrial Marketing Management, 30, 391-402. http://dx.doi.org/10.1016/S0019-8501(01)00153-5

Socialbakers. (2012). Study: Auto Brands tops in Facebook Engagement. Retrieved from http://allfacebook.com/socialbakers-engagement-1q_b87491

Torcy, G. D. (2002). A New Wave in Creating Customer Satisfaction. Journal of Database Marketing, 9(4), 366-370. http://dx.doi.org/10.1057/palgrave.jdm.3240085

Trainor, K. J. (2012). Relating Social Media Technologies to performance: a capabilities-based perspective. Journal of Personal Selling \& Sales Management, 32(3), 317-331. http://dx.doi.org/10.2753/PSS0885-3134320303

Ulaga, W., \& Eggert, A. (2003). Developing a standard scale of relationship value in business markets: Development of a measurement scale. 17th Annual IMP Conference Proceedings, 1-38.

Vansnick, R. (2011). Quel temps de réponse pour un community manager? Retrieved from http://www.mycommunitymanager.fr/quel-temps-de-reaction-pour-un-community-manager/

Vargo, S. L., \& Lusch, R. F. (2004). The four services marketing myths: Remnants from a manufacturing model. Journal of Service Research, 6(4), 324-335. http://dx.doi.org/10.1177/1094670503262946

Woodcock, N., Green, A., \& Starkey, M. (2011). Social CRM as a business strategy. Journal of Database, Marketing \& Customer Strategy Management, 18(1), 50-64. http://dx.doi.org/10.1057/dbm.2011.7

Yorgey, L. A. (2002). 10 CRM Trends to Watch in 2002. Target Marketing, 25(3), 82-86.

\section{Copyrights}

Copyright for this article is retained by the author(s), with first publication rights granted to the journal.

This is an open-access article distributed under the terms and conditions of the Creative Commons Attribution license (http://creativecommons.org/licenses/by/3.0/). 